\title{
ANALYSIS OF THE HERALDIC ELEMENTS IN THE BUILDING AND THE DOCUMENTS REGARDING THE HUREZI MONASTERY, VALCEA COUNTY, ROMANIA (1691-1714)
}

DOI: http://dx.doi.org/10.18509/GBP.2020.77 UDC: 726.7(498)"1691/1714"

\author{
Laurentiu Stefan Szemkovics ${ }^{1}$ \\ Camelia Teodorescu ${ }^{2}$ \\ Vasile Pop ${ }^{3}$ \\ Andrei Ducman ${ }^{2}$ \\ Nicoleta Bira ${ }^{4}$ \\ ${ }^{1}$ National Central Historical Archives, Bucharest, Romania \\ ${ }^{2}$ Faculty of Geography, CAIMT (Research Center for Integrated \\ Analysis and Territorial Management), University of Bucharest, Romania \\ ${ }^{3}$ St. Elefterie Church, Bucharest, Romania \\ ${ }^{4}$ Middle School "Spiru Haret" Oltenita City, Calarasi, Romania
}

\begin{abstract}
The study aims to highlight part of the documents issued by Constantin Brâncoveanu, the lord of the Wallachia (1688-1714), in which he specifies how the Hurezi Monastery was built (the most representative construction in Brancovan style), how it was endowed with the estates, villages, mountains and some customs house duties from Vâlcea, Dolj, Gorj, Mehedinți and Ilfov counties, presenting also the seals that authenticate them, but also different emblems painted on documents and carved in this place of worship located in Vâlcea county, Romania. The church of the monastery also houses the tomb of the ruler, which yet remained un-used, because Constantin Brancoveanu is buried at the church of New Saint George in Bucharest. The monastery was an important cultural center, where the ruler founded the library, which has still remained with the name of "Constantin Brâncoveanu's Library" and which currently holds about 4000 volumes. By the means of sigilography and heraldry, we have described both the seal of the most solemn document given to the monastery and these heraldic compositions, explaining also the significance of the component elements. While designing and documenting the study, I took into account the interest that can raise the seals that validate some documents, but also the emblems painted or sculpted in this monastery, upon specialists, historians and the general public. These heraldic and sigilographic sources can serve to better understand historical phenomena, as well as to identify the figure around which this religious establishment is built and dedicated to. Also, through this study we intend that the heraldry and sigilography should be restored to the important place that is appropriate to them among all the auxiliary disciplines of history.
\end{abstract}

Keywords: coats of arms, monastery, seal, heraldry, sigilography

\section{INTRODUCTION}

The Hurezi monastery, erected in 1693, [9], [10] by the ruler Constantin Brâncoveanu, included in 1995 in UNESCO heritage, is today a major tourist attraction [12], [11], [13]. The Hurezi monastery, built by the craftsmen Manea the masonry head, Istrate the wood carpenter and Vucașin Caragea the stone craftsman [1], is considered today the largest 
ensemble of medieval Brancovan-style architecture that has been preserved in the Romanian Country [4]. The ensemble is composed of the actual church of the monastery (the founder of which was the ruler Constantin Brâncoveanu), located in the center, dedicated to the good name of "Saints Emperors Constantine and Elena", the sick-healing prayer church, dedicated to "The Assumption of the Mother of God" (the foundation of the Lady Marica, the ruler's wife), the hermitage of "Holy Apostles Peter and Paul" (founded by John the Archimandrite, the abbot of the monastery) and the hermitage of "Holy Stephen" (founded by Stephen, one of the four sons of the ruler) [10], [12].

Both at this monastery and at the National Archives of Romania, tourists can discover the architecture, sculpture, religious art, coat of arms, flag signs, but also, from case to case, they can search for documents and other material traces that make reference to the objective that will be visited.

I have described and rendered the heraldic emblems that are preserved in the institutions mentioned above, which were painted on documents or carved on buildings or integral parts. We did not insist on the content of the documents that included these heraldic compositions, on their importance as historical sources. We insisted on the description, reproduction and symbolism of the coats of arms and flag signs or emblems that may contribute to highlighting the artistic activity of the sponsor or the issuer, representing a rich source for painting and sculpture from the time they were created. This current presentation is part of the series of events meant to highlight the Hurezi Monastery, as well as to praise the famous ruler Constantin Brâncoveanu, especially that by the Government Decision of Romania no. 1167/2013, the year 2014 was declared "Brâncoveanu Year", to commemorate 300 years since the martyrdom of the Brâncoveanu family members.

\section{METHODOLOGY}

Regarding the method used in this study, we went through the following steps:

1. Identification of the institutions in Romania where there are or that have such heraldic compositions that refer to the Hurezi Monastery;

2. Visiting these buildings and researching the heraldic remains, whether they were reproduced on paper, parchment or any other material;

3. Analysis of the flags' coats of arms and coats of arms in accordance with the heraldic norms and taking into account the recommendations of the former International Sealography Committee;

4. Bringing these testimonies of the past to the knowledge of the interested public, through various manifestations, visits, works or specialized studies, as well as by promoting, for tourist purposes, the ecclesiastical heraldic testimonies and the institutions holding them.

\section{RESULTS AND DISCUSSIONS}

A. At the Central National Historical Archives of Bucharest, the "Paper Rolls""Suluri" collection, no. 9, there is the royal document of ownership hrisov-the solemn document, of April 25, 1695, written on parchment (3330 x 345 mm), in Romanian, with Cyrillic characters, some words in Slavonic, given by the ruler Constantin Brâncoveanu for the Hurezi Monastery [11]. In the frontispiece of the document of ownership (hrisov) there appears the heraldic coat of arms of Wallachia (figure 1) consisting of: a round shield, loaded with a silver eagle, fully rendered, with the body well contoured, with the 
head turned to the rightside, standing with its feet on a mountain, keeping a golden Latin cross in its beak, holding four leaves of linden between its wings, flanked by two silver cherubs, aureolated with gold. The shield, bordered with white acanthus leaves, having golden dots at their ends, with a golden circle on the inside, and a silver cloud on the outside, has on the lateral sides, the inscription written in Slavonic language, on four lines, fulfilled with a golden solution, with the following words:"I CONSTANTIN BASARAB VOIEVOD, BY GOD'S WILL, LORD OF ALL THE WALLACHIA" The tiulature is, as well, flanked to the left by three cherubims, to the right by two others, and on the inside, at the bottom, by another two cherubims. The heraldic composition is included in a cartridge supported, at the corners, by four angels coming out of the clouds, and at the top by four cherubs, of which two are larger, having two smaller ones just between them.

At the top there is painted a string of clouds, with three concavities, Jesus Christ coming out from the central one; Jesus's image is flanked by the sun with golden rays, a crescent of silver, as well as by eight cherubims of variable size, four on the right, four on the left. At the bottom, another wavy cloud band, from the central part of which two characters seem to come out, facing towards the viewers, the one on the left holding an open book on the knees, keeping it by the left hand, with the right finger pointing to the writing, while the other character on the rightside appears clothed in priest robes, holding the Bible with his left hand on his chest, and with his right finger pointing to the other; the characters are flanked by two cherubims and the words written in Slavonic, with abbreviations. Prophets Solomon and David are represented on the flanks and eight cherubs of different sizes are painted under the cloud; all the characters, angels and cherubims are golden [11].

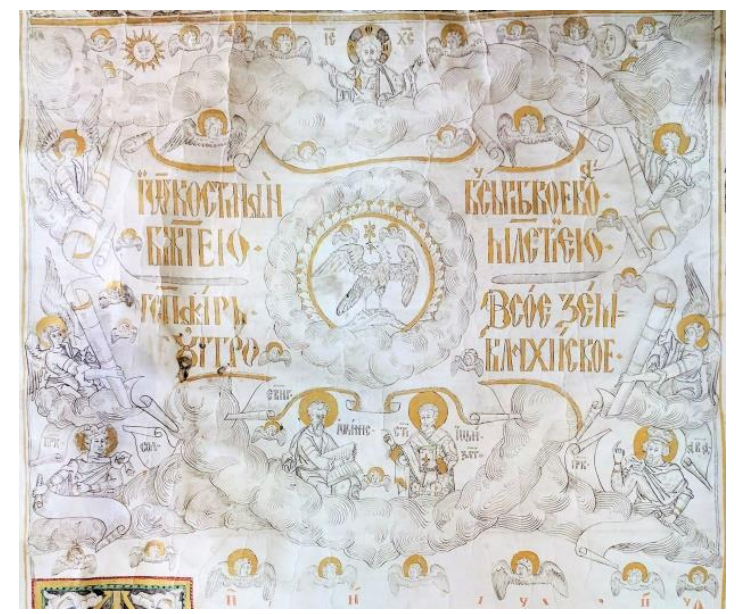

Figure 1. The royal document of ownership (hrisov) belonging to Constantin Brancoveanu, issued on April 25, 1695 (frontispiece).

At the big church of the Hurezi Monastery [14], which has been dedicated to the "Holy Emperors Constantine and Elena", above the entrance door, in a marble frame, there are carved, in excision (relief), the heraldic coat of arms of Wallachia and the coat of arms of the Cantacuzino family (figure 2), [14], [10]:

- round shield, formed by a garland of laurel leaves, loaded with the eagle, rendered entirely and front-viewed positioned, with the wings open, with the head and neck positioned in the pall - vertically, standing with the feet on a mountain, holding a Latin cross in the beak, also arranged in the pall; the bird is flanked by a sun with 11 rays, near the head, to the rightside, and by a new moon portion-the crescent to the leftside; 
- round shield, similar to the one above, loaded with the bicephalous eagle, having a closed crown above, between the ends, holding in the right claw the scepter finished in lily flower, while holding the sword tight in the left claw. Between the two coats of arms there appear two cherubims-symbol of wisdom and intelligence, but positioned in the fascia.

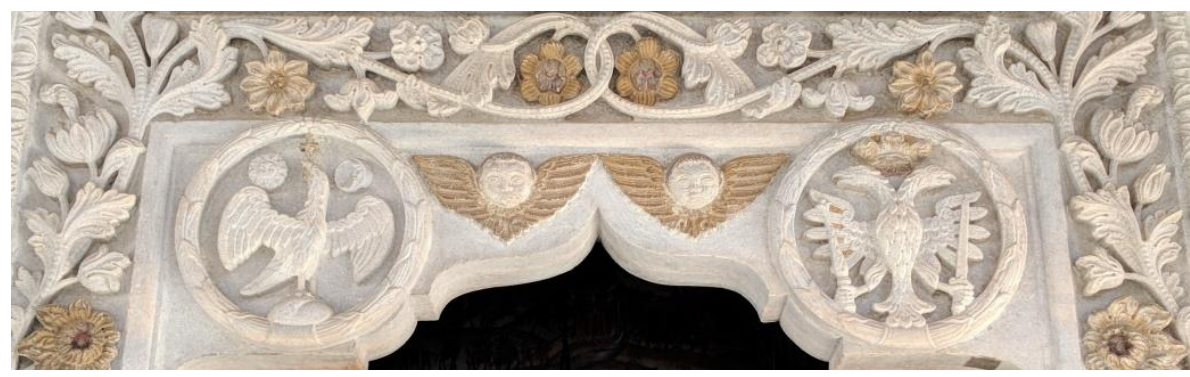

Figure 2. The heraldic coat of arms of Wallachia and the coat of arms

of the Cantacuzino family above the door at the entrance to the large church of the Hurezi Monastery.

C. The oriel/watch- tower in the Hurezi Monastery (figure 3), a "true swan song of Brancovan architecture" [4], bearing the name of its patron Dionisie Bălăcescu [5], [14], [13], (egumen of this monastery between 1748-1778) [2], was built in 1753 [8], [3], having a vault supported by five carved stone columns, in particular, with acanthus- stalks and leaves of acanthus and grooved grooves, with truncated capitals decorated with animal motifs and with the emblems of Wallachia, Moldavia and the Cantacuzino family, while the access is made on the stairs made by the stone master Joseph [8], [3], [6].

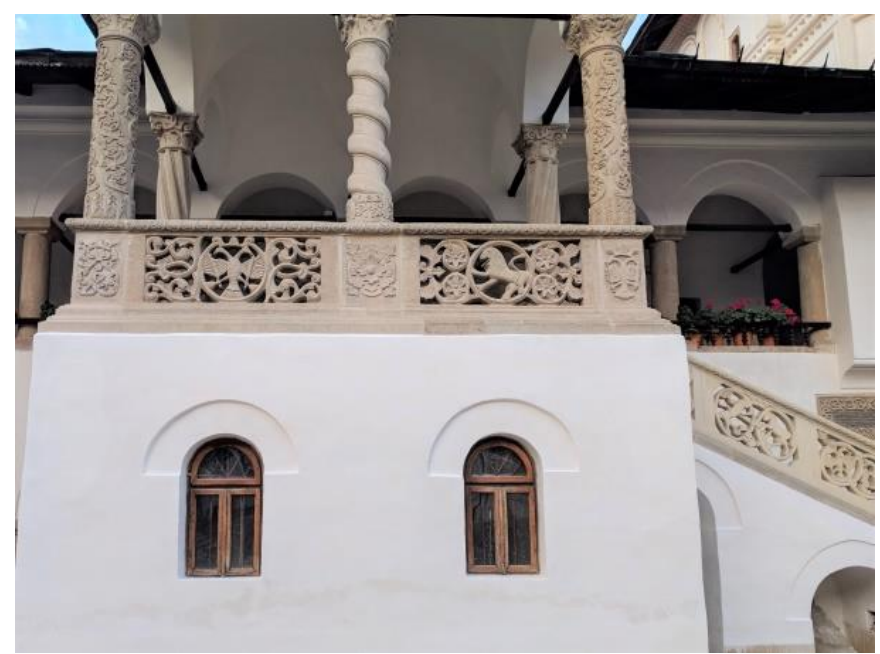

Figure 3. The oriel/ watch-tower of Dionisie Bălăcescu, located inside the Hurezi Monastery (front view)

The oriel/ watch-tower of Dionisie Bălăcescu has, on the front, left and right sides, three stone-carved banniesters, plus another banniester on the access stairs just the same type, comprising, besides herbal and floral ornaments, several heraldic compositions.

Four shields-from right to left are carved on the front balustrade (figure 4):

a) at the base of the left column, carved in excision: a heart-shaped shield, with edges of acanthus leaves, turned with the tip upwards, loaded with a hexagon-symbol of labor, rigor and collective effort, with larger right and left sides, ornamented on the outside, on the flanks, with two small acanthus leaves, above a heraldic rose-which symbolizes special merits; the shield is stamped by an open crown, with three 
fleurons, in the form of acanthus leaves, interspersed with two corners, each ending with a pearl;

b) manufactured by fretwork: a round shield, loaded with the bicephalous eagle, rendered in full and front-view positioned, with the wings opened and positioned in the fascia-horizontally, crowned with an open crown with three fleurons, holding in its claws the scepter finished in lily flower and the sword-the coat of arms of the Cantacuzino family; the tenants or supporters of the shield are twisted acanthus plants; c) manufactured by fretwork: a round shield, loaded with a leopardized lion-a lion represented as passing and staying in the leopard's position, but represented in profile [7], rendered sitting, with mouth open and tongue removed, with front paws extended, supporting, on the inside, the shield, with the hind legs curling (attached to) the shield also on the inside, with the tail past between the legs, waving upwards, and whose extremity reaches the left flank; the tenants or supporters of the shield are acanthus plants with four flowers, two on the right, two on the left;

d) at the right edge of the bannister, at the base of the column, engraved in excision, the same bicephalous eagle, yet simple, without being framed inside the shield. At the base of the central column, which is spiral, there is carved, in excision, an open flower of rhododendron - symbol of elegance and beauty.

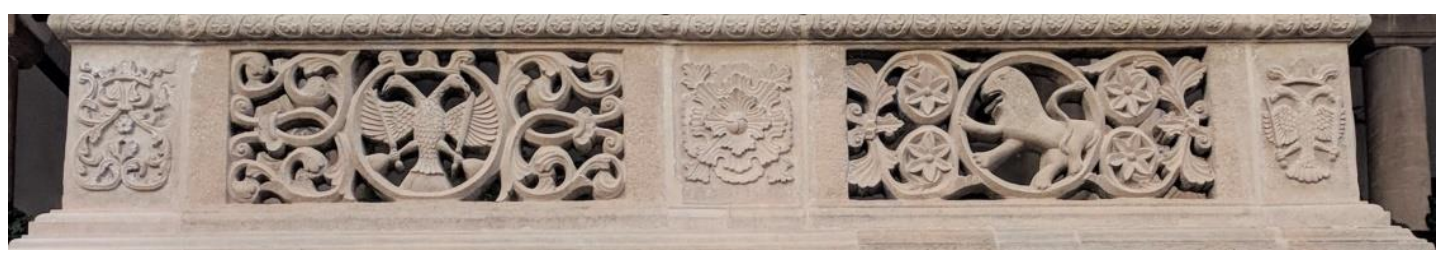

Figure 4. The bannister in front of Dionisie's oriel/ watch-tower

On the bannister on the left side of the oriel/ watch-tower (figure 5) there are carved three emblems/ logos (from right to left):

a) manufactured by fretwork: a round shield, loaded with the bicephalous eagle, rendered entirely and front - view positioned, with the wings open and positioned in fascie - horizontally, crowned with an open crown with three fleurons, holding the scepter/mase and sword - signs of power in its claws; the tenants or supporters of the shield are twisted acanthus plants;

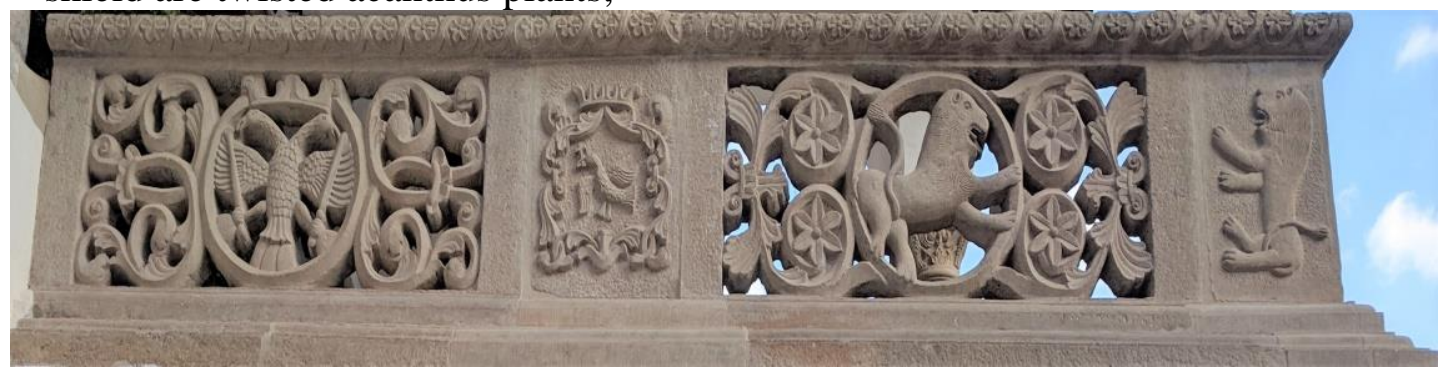

Figure 5. The bannister on the left side of Dionisie's oriel/ watch-tower

b) at the base of the spiral column, carved in excision: a shield with irregular edges, made of acanthus leaves, loaded with a bird rendered from the profile oriented towards the heraldic right, with the wings open, the right one being displayed in the pall vertically, while the left appears in the fascia - horizontally; the shield is stamped by an open crown, with five fleurons - heraldic coat of arms of Wallachia.

c) manufactured by fretwork: a round shield, loaded with a leopardized lion, passing to the heraldic left; the animal is rendered with the mouth open, with the front paws, 
extended, supporting, on the inside, the shield, with the hind legs curling (attached to) the shield as well on the inside, with the tail passed between the legs, waving upwards and the extremity of which is reaching the right flank; the tenants or supporters of the shield are acanthus plants with four flowers, two on the right, two on the left. At the right edge of the bannister, at the base of the column, there is carved in excision, a lion seated, with the tail passed between the legs and turned backwards.

On the bannister on the right side of the oriel/watch-tower (figure 6), at the base of the left column, there is carved, in excision, the united coat of arms: an oval shield, loaded to the rightside with the bird, outlined in profile, holding in its beak a Latin cross positioned in pall - vertically, and at the leftside with the head of the bour front-view positioned, with the ears arranged horisontally and the horns in the band and, respectively, in the bar; above them, in the chief part - honorable piece representing the upper third of the shield, there is, from right to left, the circumvallated crescent - oriented to the left of the shield, a star with six rays and a sun with 16 rays; the shield is stamped by an open crown, with five acanthus-shaped fleurons.

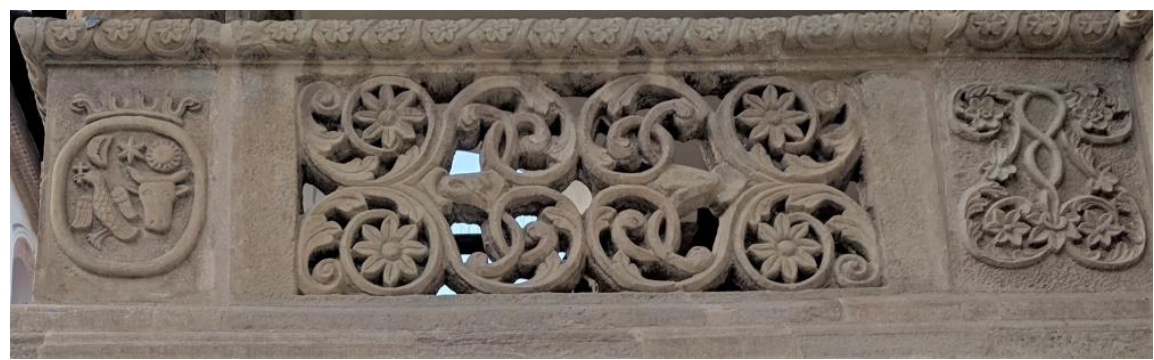

Figure 6. Bannister from the right side of Dionisie's oriel / watch-tower

The access staircase also has a balustrade (figure 7) on which there are carved, by fretwork, other six logos/emblems, of which the ones numbered with 1-2 and 5-6 (from top to bottom) are curved and alike, as follows: 1 and 5 - at the rightside, in an oval shield, there appears a leopard-lion, turned around, rendered in sitting position, with open mouth, with the front paws stretched, supporting the shield on the inside, with the tail passed between the legs, waving and whose extremity touch the left flank; the animal stands with its left rear foot resting on a twisted acanthus leaf and is supported, behind the ridge, by another ornament of acanthus leaves; 2 and 6-having a shield on the left, as well, also oval, loaded, with a wild donkey represented as surmounting a group of five stones at the base of his feet; the two shields are curled and trapped, at their point of intersection, in an open crown, with three acanthus-shaped fleurons; above the two shields, curling them, there lies another open crown, with the frontal circle adorned with rhomboid precious stones interspersed with pearls, with three fleurons also in the form of acanthus leaves, but interspersed by two corners ending each with larger pearls; at the bottom of the same shields there is a tulip flower that also curls with the petals on the flanks; 3 and 4 - two round shields, curved and interspersed, including, the one on the right - the coat of arms of the Cantacuzino family - the bicephalous eagle holding, in the claws, the sword and the scepter ending with a lily flower, while the one on the left containing the heraldic coat of arms of Wallachia - the eagle holding a Latin cross in its beak.

In the heraldry of Wallachia, the figure of the lion appears since the fifteenth century, on the objects and documents of the chancery of the rulers [1]. The supremacy over the other animals and the power of the lion determined its inclusion in the heraldic register [7]. King of all animals, the lion, symbol of power and spiritual vigilance [15], has come to 
be placed either at the entrance, as a pedestal, or at the level of the porches or flanking the access areas of the churches.

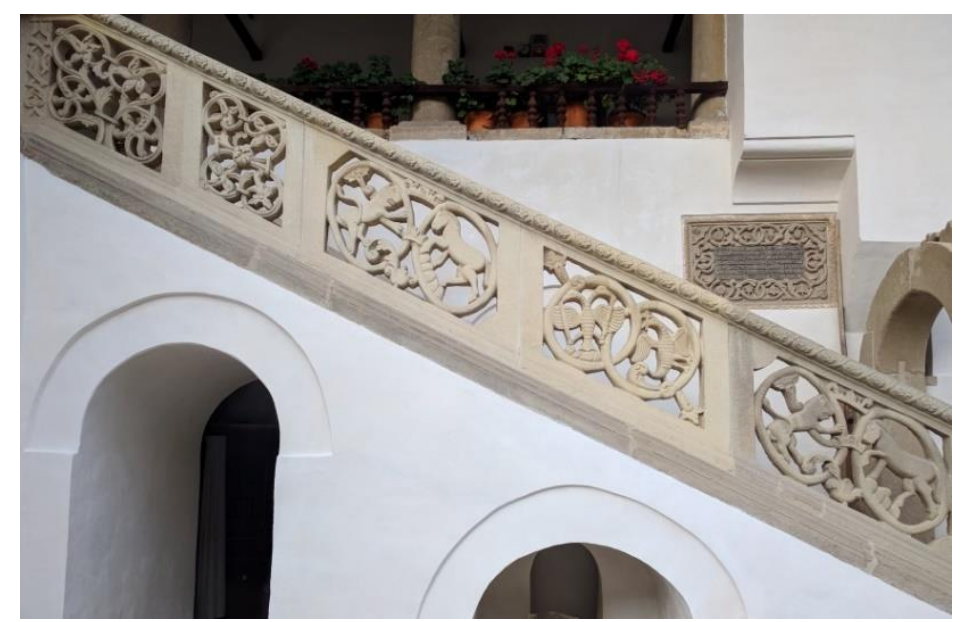

Figure 7. The bannister of the access stairs to the oriel/ watch-tower of Dionisie Bălăcescu

The wild donkey symbolizes monastic restraint and self-control. According to Iuliana Damian, the wild donkey, depicted surmounting the stones, may represent the monk's image, while the stones signify the difficulties the latter faces when he begins to ascend the steps of virtue towards God. Therefore, the two animals on the banniester of the staircase could represent: the lion, a symbol of the power of God to which the wild donkey, the monk, seeks to climb. In the religious sphere, zoomorphic motifs are elements of the divine world, of the lost paradise [3], [9]. These coats of arms on the bannisters, as well as those carved on some truncated capitals (Figures 8 and Figure 9) of some of the five columns of the mentioned oriel/watch-tower, are references to Constantin Brancoveanu, the monastery founder or builder, to the Cantacuzino family, but also to the fanariot Constantin Racoviţă who, according to the custom of the time, had first ruled in Moldavia, while in 1753 he was the ruler in Wallachia [8].
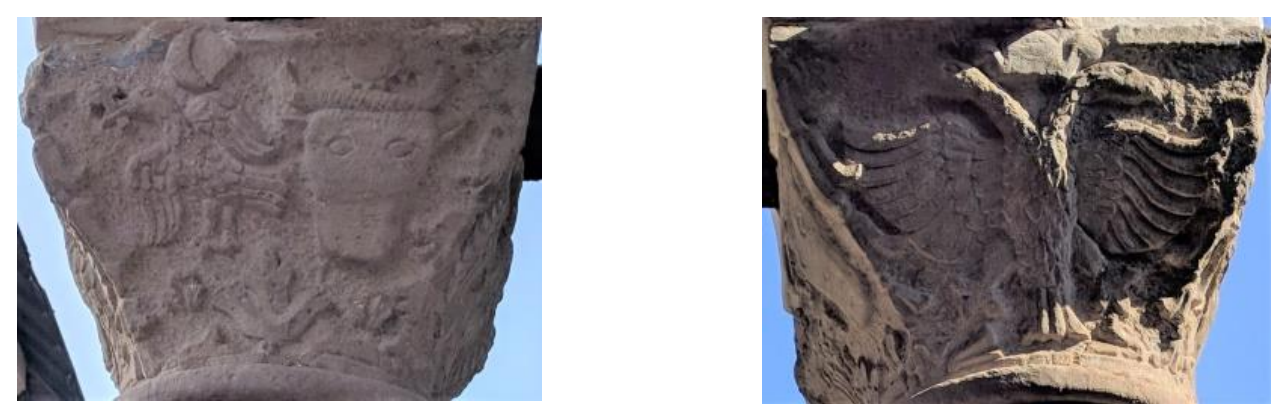

Figure 8 and Figure 9. The united coat of arms and the Cantacuzino family's coat of arms of the on the trunk capitals of two columns in Dionisie's oriel/ watch-tower

F. Culture in all its forms is the one that stands out, especially in the construction of religious settlements since the medieval and modern period. Among them, the Hurezi Monastery is also a source of attraction, transmitting today the evidence of the progress of culture expressed in architecture, painting, sculpture, heraldry and other ancillary sciences of history. Of course, according to the ones presented in the present study, there are other cultural institutions, such as archives or museums that hold emblems, coats of arms, paintings and blazons, which individualize their owners especially by the symbolism of the elements of the heraldic compositions. 


\section{CONCLUSIONS}

Heraldic sources represent a distinct part of the universal cultural heritage. The coat of arms, through the elements positioned in accordance with the heraldic norms, meant to individualize the possessor and show out his attributions. The demonstration of the scientific character of the activity of identifying the symbols used and the multitude of information transmitted by these heraldic sources, have determined an increased interest for the research of this type of signs. When accomplishing this study, I took into account the interest that these emblems and blazons can present for specialists, teachers, pupils, students, but also for tourists. I have considered that in the modernization stage of the instructional- educational process, heraldic sources can serve to better understand some historical phenomena, especially the marks made by the ancestors, but also to decipher the symbols by which the ancestors expressed their thoughts and aspirations. Also, our study is a call for other researchers to find, save, analyze and introduce in the scientific circuit, other heraldic sources of this kind, which have still remained unknown.

\section{REFERENCES}

[1] Cernovodeanu Dan, Știința și arta heraldică în România, Editura Științifică și Enciclopedică, București, 1977.

[2] Crețeanu Radu, Mari ctitori de locașuri sfinte. Dionisie Bălăcescu, Mitropolia Olteniei, vol. 25, nr. 11-12, pp. 917-925, 1973.

[3] Damian Iuliana, Câteva figuri zoomorfe de la foișorul hurezean al arhimandritului Dionisie, în vol. Constantin Brâncoveanu - domn al faptei creatoare și al jertfei sfințitoare, (antologie de studii, comunicări și articole) - în colecția Brâncoveniana, I, cu binecuvântare din partea IPS Varsanufie, Arhiepiscopul Râmnicului, volum îngrijit de Ioan St. Lazăr, Editura ROTIPO, Iași, pp. 402-412, 2014.

[4] Drăguț Vasile, Arta brâncovenească, Editura Meridiane, București, 1971.

[5] Drăguț Vasile, Arta românească: preistorie, antichitate, ev mediu, renaștere, baroc, Editura Vremea, București, 2000.

[6] Ionașcu I., Contribuții la istoricul mănăstirii Hurez după documente inedite din Arhiva Eforiei Spitalelor Civile, Scrisul Românesc, Craiova, 1935.

[7] Pastoureau Michel, Traité d'Héraldique, préface de Jean Hubert, membre de l'Institut, cinquième édition, Grands manuels Picard, 2008.

[8] Popa Corina \& Iancovescu Ioana, Mănăstirea Hurezi, Editura Simetria, București, 2009.

[9] Popescu Florentin, Ctitorii brâncovenești, Editura Bibliotheca, Târgoviște, 2004.

[10] Szemkovics Laurențiu-Ștefan, Documente de la Constantin Brâncoveanu privitoare la Mănăstirea Hurezi și la unele localități din județul Vâlcea (1691-1714), Editura Istros a Muzeului Brăilei „Carol I”, Brăila, Romania, 2017.

[11]Szemkovics Laurentiu-Stefan, Teodorescu Camelia, Alexandra Grecu, Karina Gruia, Alina Mareci \& Nicoleta Bira, The relevance of the historical monuments in the development of the cultural tourism in the main cities of the region of Oltenia, Romania, Quaestus Journal, Timisoara, Romania, vol. 12, issue. 2, pp. 42-54, 2018

[12] Teodorescu Camelia, Octavian Teodorescu, Nicoleta Bira, Badea Alin \& Badea Livia Florina, Religious and cultural tourism and the socio-economic and educational implications, Quaestus Multidisciplinary Research Journal, Romania, vol. 8, pp. 227-285, 2016

[13] Teodorescu Camelia, Radu-Daniel Pintilii, Peptenatu Daniel, Teodorescu Octavian \& Toma Sorin George, Popularizing Cultural Identity Through Religious Tourism-Socio-Economic and 
Educational Implications, International Multidisciplinary Scientific GeoConference: SGEM: Surveying Geology \& mining Ecology Management, Bulgaria, vol.3, 2016, pp. 947-954

[14] Theodorescu Răzvan, Constantin Brâncoveanu între „Casa cărților” și „Ievropa”, Enciclopedia RAO, Bucuresti, Romania2006.

[15] Velculescu Cătălina \& Guruianu Vasile, Fiziolog. Bestiar, Editura Cavallioti, București, Romania, 2001. 